\title{
Quaternary climatic changes in the Caribbean and N. South-America
}

\author{
By J. I. S. ZONNEveld, Utrecht
}

$\mathrm{Sum} \mathrm{m}$ a $\mathrm{r}$. This paper gives an inventarization of the available data concerning quaternary climatic changes in the Caribbean and the northern parts of South America.

It appears that in Colombia, N. W. Venezuela, the Leeward Islands of the Netherlands Antilles and Barbados the pluvial periods coincided with the glacial periods in higher latitudes.

The evidence for Guyana and Surinam is still insufficient to establish definitely the climatic evolution, altough the available data seem to indicate that during the glacial periods the climate was less humid than at present: this would correspond with a shifting of the "arid" belt over some 10 degrees.

$\mathrm{Zus}$ a mmenf assung. Es wurden in dieser kurzen Arbeit Literaturangaben über die quartären Klimaänderungen gesammelt, die aus dem karibischen Gebiet und den benachbarten Teilen Südamerikas bekannt sind. Man kann feststellen, daß in Kolumbien, Nordwest-Venezuela, Aruba, Curaçao, Bonaire und Barbados pluviale Perioden etwa synchron waren mit den Glazialen in Gebieten höherer Breite.

Die Daten aus Guyana und Suriname lassen zwar noch keine endgültigen Schlüsse zu, doch deutet vieles darauf hin, daß dort während der Glazialzeiten trockenere klimatische Bedingungen herrschten als heute. Das würde einer Verschiebung der „ariden“ Zone um etwa $10^{\circ}$ entsprechen.

Recent palaeoclimatic research in Africa has indicated that only part of the pluvials that were recognized in different regions of the continent, were synchronous with the glacial periods of more poleward regions (cf. Tricart, Michel and Vogt, 1957; Bernard, 1962; Büdel, 1963; Fairbridge, 1964; see also Penck, 1913).

As a general rule it appears that during the glacial periods, the boundaries of the different climatic belts shifted towards the equator. In these periods the mesothermal zones as well as the arid zones of the northern hemisphere will have moved southward and the belt of the equatorial rainforest narrowed. Even in equatorial regions eolian sands were deposited (DE HEINZELIN, 1952). Only in the zone of the climatological (or thermal) equator, some degrees southward of the astronomical one, the tropical rainforest could survive. During the interglacials the climatic belts shifted again towards the poles (cf. the diagram published by FAIRBRIDGE in 1961 and 1964).

Although the shifting of the climatic belts was not as simple as indicated above, we may accept that in the N. Sahara the pluvial periods coincided with the glacials but that in the more southern regions, pluvial periods have to be correlated with interglacial times.

For the corresponding regions in the New World, viz. the Caribbean and the adjacent part of South-America it seems worth while to gather the equivalent palaeoclimatic information in order to look for similar conclusions, although admittedly our knowledge of the Quaternary climatic changes in this part of the world is rather incomplete. In this paper dedicated to the master of quaternary research, Prof. Dr. P. WoldstedT, we will attempt to provide a brief inventarisation on this subject ${ }^{1}$ ).

Palaeoclimatic changes manifest themselves by the following phenomena:
A. movements of the levels of seas and lakes
B. changes in temperature of the seawater
C. pedological changes, incrustrations
D. changes in the vegetation
E. changes in groundwater conditions
F. changes in the geomorphological processes.

1) The author is much indebted to Prof. J. B. Bird, Montreal and Dr. K. Duphorn, Hannover, who kindly gave him some valuable references and to Mrs. M. van der MaEsen and Dr. H. Boissevain, who corrected the manuscript linguistically. 
ad A. Quaternary movements of sealevel, mostly recorded by fossil - either elevated or submerged - coastlines and terraces, are caused by the accretion or melting of great masses of inland ice. They have no direct relation with local climatic changes in regions like the Caribbean. Yet the study of former lealevels in this area is very important as it offers the possibility to compare the timing of the local climatic sequences with those of the extension and shrinking of the great ice masses.

In the Caribbean and along the north coast of South America many data are available concerning marine terraces and submarine benches. It is true that tectonic movements will have changed the original height of some of these "watermarks", especially the older ones. Yet the influence of the changed sealevels, both above and below the recent one is evident. High sealevels indicated by marine terraces (abrasion terraces as well as accumulative benches) have been mentioned by Jukes-BrownE and HARrison (1891), Molengraaff (1929), Rutten (1932), Westermann (1932), Pijpers (1933), Zonneveld (1960), DE Buisonjé (1964) and many others. Low sealevels, evidenced by drowned valleysystems and submarine benches are described e.g. by MolengraAfF (1929) and Nota (1958). These watermarks are the more valuable if - as is the case in some instances absolute datings are available.

Nota, for instance, found that his 40 and 12 fathom levels off the Atlantic coast of Guyana could be dated as resp. 11.000 and 8.000 years ago, i. e. during the late- and postglacial rise of the sealevel.

Broecker et al. (1967) show that in Barbados the lower three elevated terraces originated between 82.000 and 122.000 years B. P. after evaluation of the tectonic influence and comparison with the available data concerning seawater temperatures in the adjacent seas (Emiliani, 1965, 1966). The authors indeed evidence that the high sealevels corresponded with high temperatures of the seawater and occurred in a period known as an interglacial (the last interglacial).

In Africa the ancient coastline along the great lakes played an important role in the history of palaeoclimatic research (c. f. Nilsson, 1931; Kendall, 1965). In northern South America only the vicissitudes of the (former) Lake of Bogota, Colombia, could be taken in consideration (see ad D).

ad B. Especially the publications of Emiliani $(1965,1966)$ and Ericson c.s., 1964) give interesting data concerning the changes in temperature of the Caribbean seawater. As has been said before, these data can be correlated with those concerning higher and lower sealevels: high sealevels prove to be synchronous with high water-temperatures and vice versa.

ad C. Under certain climatic conditions deposition of carbonates (and other materials) can result in the formation of travertine masses or caliches. WILHELmY (1954) mentions suchlike fossil incrustations in northern Venezuela, espacially on the peninsula of Guajira for which he postulates climatic conditions that were more humid than the present (very dry) ones.

BAKKER (1960) found that under tropical rainforest, granites are attacked by chemical weathering in such a way that minerals like epidote and hornblende practically disappear. If, however, the forest is absent, these minerals are resistant against weathering. The same author mentions the occurrence of epidote and hornblende in a sample from a lateritic layer in the humid forest of Surinam and concludes that this must point to palaeoclimatic conditions unfavorable for humid tropical forests.

ad D. A very important indicator for palaeoclimates is the vegetation (although it is known that the vegetation not always is apt to keep pace with the climatic changes and that sometimes other factors than climate may cause vegetational changes). Up till now quaternary palaeobotanical data are known from Costa Rica, Colombia and 
Guyana. In Costa Rica (Martin, 1964) and Colombia (van der Hammen and Gonzalez, 1960) pollenanalysis revealed that during the glacial periods the timber-line in the mountains was some $1000 \mathrm{~m}$ lower than at present times. The last mentioned authors also showed that during the periods with a high timber-line (the interglacials), the level of the Lake of Bogota was lowered, apparently due to a decrease of the precipitation. In other words: interpluvials could be correlated with interglacials.

From the lowlands of the Llanos of Colombia and Venezuela no palaeoclimatic data are known from pleistocene times. WiJMSTRA and VAN DER HAMMEN (1966) analysed some pollen out of the Llanos Orientales of Colombia, but the oldest samples only date from approximately 6.000 years B. P. In Guyana the same authors investigated a profile that yielded strata as old as $9.000-10.000 \mathrm{~B}$. P. The pollen evidence appears to point to closed dry forest or closed savanna woodland conditions during late glacial times in a region that now has a savanna character (Rupununi). Prof. Hills of McGill University, Montreal (oral communication), however, explained that the lake where the samples were taken, is in fact a kind of an oxbow lake; so it is not excluded that in former times this lake had an open connection with the Ireng River. This river drains a large area covered with different types of forests and savannas. In other words: there is a possibility that part of the pollen content of the said profile especially of the older part, does not provide information about the (former) vegetation of the proper surroundings but of the (forest) vegetation of higher parts of the drainage basis of the Ireng River.

Also in the coastal areas of Guyana VAN DER HAMMEN (1961) made some very interesting investigations. He showed that in the subsoil of Georgetown a savanna-like vegetation could be correlated with a (glacial) low sealevel. After a rise of the sealevel a (mangrove) vegetation came into the picture. Actually this mangrove vegetation itself does not point to climatic changes; it is an evidence for the ingression of the sea under influence of the rising sealevel. The savanna vegetation, however, could indicate a climate with a treeless vegetation in an area where in present times the natural conditions tend to a humid rain forest.

ad E. TAMERs $(1966,1967)$ recently published some interesting data concerning the age of groundwater masses in the neighbourhood of Maracaibo and on the peninsula of Guajira in N. W. Venezuela.

In these areas, at present, the potential evaporation is approximately four to five times higher than the precipitation. Therefore recent rainwater is not in a situation to reach the groundwater reservoir. Recharge of the groundwater basins could only have occurred during periods with more precipitation (and perhaps less evaporation), i. e. during pluvial periods. According to radiocarbon datings published by TAMERS (1967) most of the groundwater samples in the neighbourhood of Maracaibo are approximately $10.000-35.000$ years old. The pluvial period during which the recharge of the aquifer has taken place evidently coincided with the last (Würm, Weichsel, Wisconsin) glacial period. In Guajira Tamers (1966) found ages in the range of 5.000-8.000 years, the time of the Holocene climatic optimum. He concludes that here the groundwater reservoir could have been charged during a pluvial that could correspond with the period of higher precipitation recognized by Butzer (1961) in the Mediterranean regions.

ad F. Finally some geomorphological phenomena may point to alternations of pluvial and interpluvial periods in the Caribbean and the northern part of South America.

Wilhelmy (1954) called attention to the "fossil" character of the valleys of Curaçao which would reflect conditions more humid than those of recent times.

On Bonaire and Barbados Blume (1968) could establish that along the front of some cuesta-like forms slumping and spring erosion must have occurred under climatic conditions considerably more humid than at present. 
Tricart and Cailleux (1965) record an observation on Barbados where a large limestone block which during a humid period was moved downward by slumping, was recently attacked by sealevel solution. The local situation leads them to conclude that the slumping took place during the last glacial period when the sealevel was lower than at present.

A very interesting study was carried out by DE BuISONJÉ (1964) who postulates that some marine terraces (representing fringing and barrier reefs built up during periods with high sealevels) were formed under relatively arid conditions. Moreover, he found evidence that the lower sealevels coincided with more humid periods.

Recently GARNER (1967) expressed the idea that the intricate systems of rapids and waterfalls that are characteristic for many rivers in Venezuela (and other tropical regions) would be connected with a transition from dry to humid conditions: the rivers that had originated during this transition would not yet have had the opportunity to degrade their beds and would only find their way in unconcentrated and unorganized channel systems ("rivers in the making"). In my opinion, however, this view is based on a misconception concerning the evolution and character of rivers in humid tropical regions (cf. ZoNNEVELD, 1952, 1968; Tricart, 1959; BaKker, 1960).

The observations, made by GALON $\left(1966^{\mathrm{a}}, 1966^{\mathrm{b}}\right)$ are more important in terms of palaeoclimatic evidence. GALON refers to erosional forms which apparently were moulded under semiarid conditions (he found the same "branched slope incisions" in action in action in semi-arid regions) but which in present days are covered with tropical rainforest. Also ZoNNEveld (1967) mentions fossil landforms in southern Surinam, resembling fossil "lavakas", which must have originated in periods of greater extension of the savannas (actually a large part of the recent savannas in that area has to be regarded as anthropogenic).

When the data reviewed are overlooked and considered, it becomes evident that the value of the information is unequal. Some data only indicate that at one time or the other climatic changes did occur, partly in regions that are now relatively dry (Curaçao, Bonaire, N. W. Venezuela and also Barbados), partly in the regions with humid tropical climates (the northern part of South America).2)

On the other hand other data provide more exact information and concern the relation between local climatic changes and the sequence of glacials and interglacials. The evidence of Curaçao (DE Buisonjé, 1964), Colombia (VAN Der HAMmen and Gonzalez, 1960), Barbados (Tricart and Cailleux, 1965) and Maracaibo (Tamers 1967) clearly point to humid conditions during the last glacial (or part of it) and to (relative) aridity during interglacials.

The evidence from Guyana and Surinam, however, is still insufficient to establish the climatic evolution in that area, altough the available data seem to indicate that in the Guyanas the least humid conditions coincided with glacials. This would mean that during the transition from an interglacial to a glacial period the (semi-) arid zone shifted southward and that it went back again when the glacial was succeeded by the next interglacial. This would correspond with a shifting over some 10 degrees.

At present it is preferable to avoid speculation and to wait for the results of new research to be carried out in eastern Venezuela, northern Brazil and the three Guyanas.

2) One would expect that also in French Guyana such indications will be found, in spite of the information already given by CAILleux (1959) that in this country during the Pleistocene apparently no important climatic changes had occurred. 


\section{References}

BAKKER, J. P.: Some observations in connection with recent Dutch investigations about granite weathering and slope development in different climates and climatic changes. Z. Geomorph., Suppl. Bd. 1, 69-92, Berlin 1960.

BAKKer, J. P. \& MüLLER, Zweiphasige Flußablagerungen und Zweiphasenverwitterung in den Tropen unter besonderer Berücksichtigung von Surinam. Lautensach-Festschrift, 365-397, Stuttgart 1957.

Bernard, E. A.: Théorie astronomique des pluviaux et interpluviaux du Quaternaire africain. Mém. Ac. Roy. Sci., O. M. 12, Bruxelles 1962.

Blume, H.: Zur Problematik des Schichtstufenreliefs auf den Antillen. Abst. 58. Jahrestagung Geol. Ver., Göttingen 1968.

Broecker, W. S. et al.: Milanchowitch hypothesis supported by precise dating of coral reefs and deep sea sediments. Science 159, 297, Lancaster 1968.

Büdel, J.: Die pliozänen und qartären Pluvialzeiten der Sahara. Eiszeitalt. u. Gegenw. 14, 161187, Ớhringen 1963.

Buisonjé, P. DE: Marine terraces and sub-aeric sediments on the Neth. Leeward Islands, Curaçao, Aruba and Bonaire, as indications of quaternary changes in sea level and climate I and II. Proc. Kon. Ned. Akad. v. Wet., Ser. B 67, 1, 60-79, Amsterdam 1964.

Butzer, K. W.: Modifications of climate in the arid zone since the Pliocene. - In: History of Land Use in the Arid Zone, UNESCO, Paris 1961.

Cailleux, A.: Études sur l'érosion et la Sédimentation en Guyane. Mém. expl. Carte géol. de la France, Dept. Guyane Française, 49-73, Paris 1959.

Emiliani, C.: 018/016 variations in Marine Carbonates and sea water during the late Cenozoic. Abst. VII, I.N.QU.A.-Congress (Denver), 129-130, Denver 1965. - - Paleotemperature analysis of Caribbean cores P 6304-8 and P 6304-9 and a generalised temperature curve for the past 425.000 years. Journal of Geology 74, 109-124, Chicago 1966.

Ericson, D. B. et al.: The pleistocene Epoch in Deep sea Sediments. Science 146, 723. Lancaster 1964.

Fairbridge, R. W.: Convergence of evidence on climatic change and ice ages. Ann. New. York Acad. Sci. 95, 1, 542-579, New York 1961. - - Eiszeitklima in Nordafrika. Geol. Rdsch. 54, 399-414, Stuttgart 1964.

Galon, R.: Klimamorphologische Probleme der Tropen am Beispiel von Venezuela. Wiss. Veröffentlichungen des deutschen Inst. f. Länderkunde, Leipzig, N.F. 23/24, 259-267, Leipzig 1966. - - Niektóre problemy geograficzne Wenezueli. Some geographical problems of Venezuela. Przeglad Geograficzny t XXXVIII, z 4, 651-671, Warszawa 1966.

Garner, H. F.: Rivers in the making. Sci. American 216, 84, New York 1967.

Hammen, Th. v. D.: The quaternary climatic changes of northern South America. Ann. New York Ac. Sci. 95, 1, 676-683, New York 1961.

Hammen, Th. v. D. \& Gonzalez, E.: Upper Pleistocene and Holocene climate and vegetation of the "Sabana de Bogotá" (Colombia, South America). Leidse Geol. Med. 25, 261-315, Leiden 1960.

Heinzelin, J. DE: Sols, paléosols et désertifications anciennes dans le secteur Nord oriental du Bassin du Congo. Publ. I.N.E.A.C., Bruxelles 1952.

Jukes-Browne, A. J. \& Harrison, J. B.: The geology of Barbados, I. The Coral Rocks of Barbados and other West Indian Islands. Quart.-Journ. Geol. Soc. 47, 197-250, London 1891.

Kendall, R. L.: Climatic change in East Africa: The evidence from Lake Victoria. Abstr. VIIth I.N.Q.U.A.-Congress (Denver), 264, 1965.

Martin, P. S.: Paleoclimatology and a tropical pollen profile. Report on the VIth Intern. Congress on Quaternary, Warsaw, 1961, II, 319-323, Warszawa 1961.

Molengraaf, G. J. H.: Geologie en Hydrologie van het eiland Curaçao. Diss., Delft 1929.

Nilsson, E.: Quaternary glaciations and pluvial lakes in Br. East Africa. Geogr. Ann. 13, 249 349, Stockholm 1931.

Nota, D. J. G.: Sediments of the Western Guiana Shelf, Thesis. Utrecht 1958.

PencK, A.: Die Formen der Landoberfläche und die Verschiebungen der Klimagürtel. Sitz.-Ber Kgl. Preuß. Akad. Wiss., Halbb. I, 4, 77-97, Berlin 1913.

PIJPERs, P.: Geology and Palaeontology of Bonaire (D.W.I.). Thesis, Utrecht. 1933.

Rutten, L. M. R.: De geologische geschiedenis der drie Nederlandse Benedenwindsche Eilanden. De W.I. Gids XIII, 401-441, 1932.

TAMERs, M.: Groundwater recharge of aquifers as revealed by naturally occured radiocarbon in Venezuela. Nature 2, 12, 1966, 489-492, London 1966. - - Radiocarbon ages of groundwater in an arid zone unconfined aquifer. In: Isotope techniques in the hydrologic cycle. Am. Geophys. Union, Geophys. Monogr. Ser. 11, Washington, D. C. 1967. 
Tricart, J.: Observations sur le Faconnement des rapides des rivières intertropicales. Bull. Sect. Géogr. Com. Trav. Hist. et Sci., 1958, 289-313, Paris 1959.

Tricart, J. \& Cailleux, A.: Traité de Géomorphologie, Tome V, Le modelé des régions chaudes. Forets et savannes. S.E.D.E.S., Paris 1965.

Tricart, J., Michel, P. \& Vogt, J.: Oscillations climatiques quarternaires en Afrique occidentale. Resumées Vme Congr. Intern. I.N.Q.U.A., Madrid, 187-188, Madrid 1957.

Westermann, J. H.: The Geology of Aruba. Diss. Utrecht 1932.

Wilhelmy, H.: Die klimatologische und pflanzengeographische Entwicklung des Trockengebietes am Nordrand Südamerikas seit dem Pleistozän. Die Erde VI, 244-273, Berlin 1954.

Wijmstra, T. A. \& Hammen, T. v. D.: Palynological data on the history of tropical savannas in northern South America. Leidse Geol. Med. 38, 71-90, Leiden 1966.

Zonneveld, J. I. S.: Watervallen in Suriname. T.K.N.A.G., LXIX, 499-506, Amsterdam 1952. - Een luchtfoto-onderzoek op de Benedenwindse Eilanden. T.K.N.A.G. LXXVII, 389399, Amsterdam 1960. - - Enkele luchtfoto's van de Sipaliwini-savanne in Z. Suriname, with summ. in English. Geogr. Tijdschr., N. S. 1, 286-298, Amsterdam 1967. - - Some aerial photographs from the Surinam jungle. Geogr. Tijdschr., N. S. 1. Amsterdam 1968 (in press).

Manuskr. eingeg. 20. 5. 1968.

Anschrift des Verf.: Prof. Dr. J. I. S. Zonneveld, Utrecht, Drift 21, Geografisch Instituut der Rijksuniversiteit, Utrecht, Nederland. 